Secession of States and Self-determination in contemporary International Law

\title{
Does a Right of Remedial Secession exist under International Law?
}

\author{
Esperanza ORIHUELA CALATAYUD*
}

\begin{abstract}
The question of the existence of a right of remedial secession under international law has been raised as a possible solution to serious human rights and international humanitarian law violations. The current controversy lies in determining whether such a right is recognized by a rule of general international law, or whether it should be viewed as only a custom in formation. This paper looks at the reasons that make it possible to speak of a right of remedial secession, the legal basis for such a right, the circumstances in which it might be framed, and international practice in order to determine its status in international law.
\end{abstract}

Keywords: Remedial secession - Human rights violations - International humanitarian law violations - Internal aspect of Self-determination - General International Law

\section{(A) INTRODUCTION}

The existence of a right of remedial secession is one of the issues arising in international law (IL) as a result of the evolution of the principle of self-determination of peoples. The issue reached The Hague when the United Nations General Assembly (UNGA) asked the Court to determine whether the unilateral declaration of independence of Kosovo was in accordance with IL. However, the Court declined to pronounce itself on it. This silence has left open doubts regarding its recognition and scope in IL.

In this article, I share some thoughts that I have had on the matter since the seminar organizers made their original request. The aim is to determine the status of IL regarding remedial secession and try to answer some questions the subject raises, namely: whether it is a right recognized by IL or only a custom in formation; what its legal basis is, or would be; and in what cases and under what conditions it is, or could be, admitted.

To this end, I begin by specifying the reasons that make it possible to speak of a right of remedial secession in the context of the principle of self-determination. I indicate the legal basis for this right, and the circumstances in which it is, or should be, framed. I conclude with a discussion of its status in IL.

* Professor of Public International Law, University of Murcia. 


\section{(B) WHY A RIGHT OF REMEDIAL SECESSION?}

The idea of a possible right of remedial secession under IL is a result of IL's neutrality regarding the ways in which new states can emerge. Although IL does not recognize a right of secession to which any people wishing to secede from the state to which they belong may aspire, neither does it prohibit the separation of part of a state's territory ${ }^{1}$. Should that occur, IL is willing to accept new states as long as they meet the essential conditions for statehood.

It is precisely this lack of a right of secession that gives rise to the possibility of a narrower right of remedial secession under $\mathrm{IL}^{2}$, i.e. a right to independence as a means of addressing certain conflictive situations or crises, specifically, those involving massive and systematic human rights and international humanitarian law (IHL) violations.

The linking of this right with the self-determination of peoples is a consequence of how this fundamental principle of IL has evolved. It is related to the legitimacy that the principle grants to the independence of certain peoples (colonial) or situations (occupation) that are contrary to the purposes and principles of the UN Charter.

Although initially the principle of self-determination of peoples was invoked in relation to decolonization and was highly focused on the independence of colonial territories, ${ }^{3}$ its efficacy does not end there. On the contrary, its inclusion in the International Covenants on Human

I This point of view is widely shared. In this sense, i.e., A. Buchanan, Justice, Legitimacy, and SelfDetermination. Moral Foundations for International Law, (Oxford University Press, Oxford, 2004), at 333; J. Crawford, The Creation of States in International Law, Second Edition, (Oxford University Press, Oxford, 2006), 388-42I, at 388-389; J.F. Escudero Espinosa, Self-Determination and Humanitarian Secession in International Law, (Springer, Cham, 2017), at 37-40; CH. Walter and A. Ungern-Sternberg, "Introduction. Self-Determination and Secession in International Law. Perspectives and Trends with Particular Focus on the Commonwealth of Independent States", in CH. Walter and A. Ungern-Sternberg, and K. Abushov, Self-Determination and Secession in International Law, (Oxford University Press, Oxford, 20I4), I-9., at p. 3; It is also the position that some States kept up before the Court in the advisory opinion of the Accordance with international law of the unilateral declaration of independence in respect of Kosovo, ICJ Reports, 20IO: Germany (pp. I8-20); France (pp. 3539), or Ireland (pars. 18-20) that references to teachings of qualified publicist. Also is the position of United Kingdom (pars. 5.I2-5.33). Also ICJ, Legal Consequences of the Construction of a Wall in the Occupied Palestinian Territory, Advisory Opinion, ICJ Reports, (2004), at par. 84; Committee on the Elimination of Racial Discrimination (CERD) in its XXI General Recommendation (1996), par. 6 and the of the Supreme Court of Canada, Reference re Secession of Quebec, 1998, 2 S.C.R. 217, par. II2.

2 An antecedent of the recognition of a limited right of secession is found in 1920 decision of the Commission appointed by the League of Nations in the Aaland Islands Case. After refusing the right of a part of the population to separate from the State of which it is a part, as being contrary to the order and stability of international relations and to promote international anarchy, the Commission admitted the separation as an exceptional solution, a last resort, when a State does not show the will or capacity to establish or apply fair and effective guarantees.

3 This time is called by the Professor Paz Andrés as the apotheosis of the independence. P. Andrés Sáenz de Santamaría, "La libre determinación de los pueblos en la nueva sociedad internacional", en Cursos Euromediterráneos Bancaja de Derecho Internacional, Vol I, (1997), II3-203, at 153. 
Rights together with the wording used ${ }^{4}$ show that the self-determination of peoples is no longer limited to the colonial phenomenon and broaden both its content and its beneficiaries. As Professor Paz Andres notes, the reference to peoples is understood as the set of peoples living in an independent sovereign states.

Following its application during decolonization, it was logical to wonder whether selfdetermination might serve other purposes and principles of the UN and whether independence should be considered the way to achieve them. With regard to the first question, there is no doubt that one of these purposes and principles is the development and encouragement of respect for the human rights and fundamental freedoms of all'. It is in this context that the possibility of secession as a remedy for situations involving human rights and IHL violations is raised.

As for the second point, it must be recalled that, whilst all peoples have the right to selfdetermination, its fulfilment need not necessarily take the form of secession from the state to which a people belong. Such a possibility would be a destabilizing factor for international society and for states themselves?

(C) THE LEGAL BASIS OF THE RIGHT OF REMEDIAL SECESSION

4 Both the International Covenant of Civil and Political Rights and the International Covenant of Economic, Social and Cultural Rights establish in its first disposition that: "I. All peoples have the right of selfdetermination. By virtue of that right they freely determine their political status and freely pursue their economic, social and cultural development. 2. All peoples may, for their own ends, freely dispose of their natural wealth and resources without prejudice to any obligations arising out of international economic co-operation, based upon the principle of mutual benefit, and international law. In no case may a people be deprived of its own means of subsistence. 3. The States Parties to the present Covenant, including those having responsibility for the administration of Non-Self-Governing and Trust Territories, shall promote the realization of the right of selfdetermination, and shall respect that right, in conformity with the provisions of the Charter of the United Nations." (BOE de 30 de abril de 1977).

5 P. Andrés Sáenz de Santamaría, supra n. 3, p. 153-154. The development and the evolution of the legal concept of people were advocated by Milan Sahovic, "Codification des principes du Droit International des relations amicales et de la coopération entre les Etas”, R. des C., vol I37, (1972), 24I-3IO, at 298-299.

6 Article I.3 of the UN Charter.

7 In this sense, J.A. Pastor Ridruejo, "Le Droit International à la veille du vingt et unième siècle: normes, faits et valeurs. Cours General de Droit International Public", R. des C., t. 274, (1998), 9-308, at I48; A. Remiro Brotóns, "¿Un derecho internacional de separación del Estado?, Meridiano CERI, diciembre 1996, at 9; R. Riquelme Cortado, Derecho Internacional. Entre un orden global y fragmentado, (Biblioteca Nueva, Madrid, 2005), at 163; P. Thornberry, "The Democratic or Internal Aspect of Self-Determination with some remarks on Federalism", in CH. Tomuschat (ed.), Modern Law of Self Determination, (Dordrecht, I993), IOI-I38, at II8; CH. Tomuschat, "Self-Determination in a Post-Colonial World", in CH. Tomuschat (ed.), Modern Law of Self Determination, (Dordrecht, 1993), I-20, at IO; In this sense many States manifested before the ICJ in the advisory opinion of the Accordance with international law of the unilateral declaration of independence in respect of Kosovo, ICJ Reports, (2010), at 23. 
The main argument in support of the existence of a right of remedial secession can be found in Resolution 2625 (XXV), whose description of the principle of equal rights and selfdetermination of peoples, as Thornberry observes, goes beyond the colonial context and the obsession with independence ${ }^{8}$ to add the following safeguard clause:

"Nothing in the foregoing paragraphs shall be construed as authorizing or encouraging any action which would dismember or impair, totally or in part, the territorial integrity or political unity of sovereign and independent States conducting themselves in compliance with the principle of equal rights and self-determination of peoples as described above and thus possessed of a government representing the whole people belonging to the territory without distinction as to race, creed or colour."

A similar reference, although updated at the time of its adoption, can be found in the Vienna Declaration and Programme of Action, adopted by the World Conference on Human Rights in Vienna on 25 June 1993. Paragraph 2 of that document refers to the self-determination of peoples, although in this case it makes no reference to the grounds of discrimination. This toughens the requirement of a representative government?. The same wording was used again in the Declaration on the Occasion of the Fiftieth Anniversary of the United Nations ${ }^{10}$.

This safeguard clause links the self-determination of peoples with the territorial integrity of sovereign states in order to emphasize the need for compatibility between them. It also establishes a relationship between the self-determination of peoples and democracy, or the democratic principle, and the protection of human rights. In this regard, it recalls the need for states to conduct themselves in accordance with the aforementioned principles of equal rights and self-determination. Previously, Resolution 2625 (XXV), had provided for the duty of states to promote universal respect and observance of human rights and fundamental freedom $s^{\mathrm{II}}$.

8 P. Thornberry, "The principle of self-determination", in C. Warbrick and V. Lowe (eds.), The United Nations and the Principles of International Law, Essays in memory of Michael Akeburst, (Routledge, London and New York, 1994), 175-203, at I8r. About the Declaration, G. Arangio Ruiz, The UN Declaration on Friendly Relations and the system of the sources of International Law, (Sijthoff, Alphen aan den Rijn, 1979).

9 The paragraph I.2 in fine established that "...this shall not be construed as authorizing or encouraging any action which would dismember or impair, totally or in part, the territorial integrity or political unity of sovereign and independent States conducting themselves in compliance with the principle of equal rights and self-determination of peoples and thus possessed of a Government representing the whole people belonging to the territory without distinction of any kind."

ro A/RES/50/6, of October, 1995. In the same way, the Declaration on the Rights of Persons belonging to National or Ethnic, Religious and Linguistic Minorities, adopted by de UNGA on December I8, I992, establishes that "nothing in the present Declaration may be construed as permitting any activity contrary to the purposes and principles of the United Nations, including sovereign equality, territorial integrity and the political independence of States" (art. 8.4).

II Par. 3 of the provisions related to the principle of equal rights and self-determination of peoples established in the Declaration on Principles of International Law concerning Friendly Relations and Cooperation among States in accordance with the Charter of the United Nations. 
The relationship drawn in this clause between the self-determination of peoples and territorial integrity has not gone unnoticed ${ }^{\mathrm{r}}$ and has raised questions regarding a possible clash between two fundamental principles. These questions can be answered by looking at how it was prepared ${ }^{13}$ and how it has been interpreted by various treaty bodies responsible for monitoring the implementation of conventional human rights provisions.

As Professor Cassese notes, and other authors have confirmed, the order in which territorial integrity and the requirement of a representative government were ultimately included is not neutral and shows that territorial integrity is an essential value that must be respected by all states ${ }^{14}$. This is clear in Resolution 1514 (XV), or the Declaration on the Granting of Independence to Colonial Countries and Peoples, which warned that "[a]ny attempt aimed at the partial or total disruption of the national unity and territorial integrity of a country is incompatible with the purposes and principles of the Charter of the United Nations" ${ }^{15}$, and in Resolution 2625 (XXV), which noted that "[ $\left.\mathrm{t}\right]$ he territory of a colony or other Non-Self-Governing Territory has, under the Charter, a status separate and distinct from the territory of the State administering it". As Marcelo Kohen points out, this safeguard clause was not included with the intention of recognizing a right of secession, but rather was drafted bearing in mind the situation of peoples who were victims of racist regimes ${ }^{16}$.

Self-determination does not give rise to a right to secede from existing states. Selfdetermination is, and should be, compatible with the sovereignty and territorial integrity of the state ${ }^{17}$. This need for compatibility was noted in the Helsinki Act of $1975^{18}$ and in the

I2 Separate opinion of judge A. A. Cançado Trindade related to the Accordance with International Law of the Unilateral Declaration of Independence in Respect of Kosovo, Advisory Opinion, ICJ Reports, (2010), 594-595, par. 179 and his references to Sahovic, Arangio Ruiz or Thornberry.

I3 A. Cassese, Self-Determination of Peoples. A Legal Reappraisal, (Cambridge University Press, Cambridge, 1995), at II8-I20. For an analysis of the elaboration of this clause, see, A.G. López Martín and J.A. Perea Unceta, J.A., Creación de Estados, secesión y reconocimiento, (Tirant lo Blanch, Valencia, 20I8), at I6I-165.

I4 A. Cassese, supra n. I3, pp. II8-II9. An opinion generally accepted by the authors, i.e., I. Brownlie, Principles of International Law, ( $7^{\mathrm{a}}$ ed), (Oxford University Press, Oxford, 2008), at 289; also in 8th ed. of J. Crawford, Brownlie's Principles of Public International Law, (Oxford University Press, Oxford, 20I2), at 447; M. Shaw, International Law, $7^{\text {a }}$ ed, (Cambridge University Press, Cambridge, 2014), at 377; P. Thornberry, "The Principle of....", supra n. 8, at I8I-I83. Among the commentators of the Declaration see, G. Arangio Ruiz, "The Normative Role of the General Assembly of the United Nations and the Declaration of Principles of Friendly Relations", R. des C., t. I37, (1972), 418-742, at 570-571, and the updated version The UN Declaration on Friendly Relations and the System of the Sources of International Law, (Sijthoff, 1979), at I40.

is Para. 6 GA Res. 1514 (XV), December 14, 1960.

${ }_{16}$ M. Kohen (ed.), Secession International Law Perspectives, (Cambridge University Press, Cambridge, 2006), at Io.

${ }^{17}$ In order to make compatible the principle of sovereignty and the self-determination principle, the Declaration on Principles of International Law concerning Friendly Relations and Cooperation among States in accordance with the Charter of the United Nations notes that the territory of a colony or other non-self-governing territory has a status separate and distinct from the territory of the State administering it; and such separate and 
Charter of Paris for a New Europe of 1990. It was reiterated, in 1992, by the Secretary-General of the United Nations in his Agenda for Peace: Preventive diplomacy, peacemaking and peacekeeping $^{19}$. It was pointed out again in 1995, by the African Commission on Human and Peoples' Rights, which, in the Congrés du peuple katangais $c$. Zaire case, accepted that the people of Katanga had a right of self-determination, but warned that it had to be exercised in a way compatible with the sovereignty and territorial integrity of Zaire ${ }^{20}$. In 1998, the Supreme Court of Canada underscored it again, in its decision in the Re Secession of Quebec case $^{21}$.

distinct status under the Charter shall exist until the people of the colony or Non-Self-Governing Territory have exercised their right of self-determination...., but it is not the case of peoples and groups that are part of a State.

I8 The paragraph VIII of the Act noted that: "The participating States will respect the equal rights of peoples and their right to self-determination, acting at all times in conformity with the purposes and principles of the Charter of the United Nations and with the relevant norms of international law, including those relating to territorial integrity of States.

19 In the Report of the Secretary General (A/47/277-S/24III, June 17, 1992) we should read: "I7. The foundation-stone of this work (maintaining international peace and security) is and must remain the State. Respect for its fundamental sovereignty and integrity are crucial to any common international progress. The time of absolute and exclusive sovereignty, however, has passed; its theory was never matched by reality. It is the task of leaders of States today to understand this and to find a balance between the needs of good internal governance and the requirements of an ever more interdependent world. Commerce, communications and environmental matters transcend administrative borders; but inside those borders is where individuals carry out the first order of their economic, political and social lives. The United Nations has not closed its door. Yet if every ethnic, religious or linguistic group claimed statehood, there would be no limit to fragmentation, and peace, security and economic well-being for all would become ever more difficult to achieve. I8. One requirement for solutions to these problems lies in commitment to human rights with a special sensitivity to those of minorities, whether ethnic, religious, social or linguistic. The League of Nations provided a machinery for the international protection of minorities. The General Assembly soon will have before it a declaration on the rights of minorities. That instrument, together with the increasingly effective machinery of the United Nations dealing with human rights, should enhance the situation of minorities as well as the stability of States. 19. Globalism and nationalism need not be viewed as opposing trends, doomed to spur each other on to extremes of reaction. The healthy globalization of contemporary life requires in the first instance solid identities and fundamental freedoms. The sovereignty, territorial integrity and independence of States within the established international system, and the principle of self-determination for peoples, both of great value and importance, must not be permitted to work against each other in the period ahead. Respect for democratic principles at all levels of social existence is crucial: in communities, within States and within the community of States. Our constant duty should be to maintain the integrity of each while finding a balanced design for all".

20 As the Commission said: "The absence of concrete evidence of violations of human rights to the point that the territorial integrity of Zaire should be called to question and in the absence of evidence that the people of Katanga are denied the right to participate in Government as guaranteed by Article I3 (I) of the African Chapter, the Commission holds the view that Katanga is obliged to exercise a variant of self-determination that is compatible with the sovereignty and territorial integrity of Zaire" (par. 6). About this issue see, F. Ouguergouz and D.L. Tehindrazanarivelo, "The question of secession in Africa", in, M. Kohen (ed.), Secession International Law Perspectives, (Cambridge University Press, Cambridge, 2006), 257-296.

21 Re secession of Quebec, (1998) 2 S.C.R. 217 Supreme Court of Canada, pars. I26-I30. 
Ensuring the compatibility of the territorial integrity of states and the self-determination of peoples requires distinguishing between the two aspects of the latter noted by the Committee on the Elimination of Racial Discrimination (CERD) in General Recommendation XXI on the right of self-determination, adopted at its forty-eighth session $(1996)^{22}$. In that recommendation, the Committee underlines the need to respect the territorial integrity of states ${ }^{23}$, noting:

"In respect of the self-determination of peoples two aspects have to be distinguished. The right to self-determination of peoples has an internal aspect, that is to say, the rights of all peoples to pursue freely their economic, social and cultural development without outside interference. In that respect there exists a link with the right of every citizen to take part in the conduct of public affairs at any level, as referred to in article 5 (c) of the International Convention on the Elimination of All Forms of Racial Discrimination. In consequence, Governments are to represent the whole population without distinction as to race, colour, descent or national or ethnic origin. The external aspect of self-determination implies that all peoples have the right to determine freely their political status and their place in the international community based upon the principle of equal rights and exemplified by the liberation of peoples from colonialism and by the prohibition to subject peoples to alien subjugation, domination and exploitation." ${ }^{24}$.

The internal aspect of self-determination, aimed at any people, but especially the population of a sovereign state, must be understood as participatory democracy. This implies, first, the people's freedom to choose their political, economic, social and cultural system, which calls for the existence of mechanisms of participation by the people in the adoption of decisions ${ }^{25}$. Second, it requires respect for human rights.

The UNGA had already noted the connection between self-determination and respect for human rights in Resolution 213I (XX), of 2I December 1965, the Declaration on the Inadmissibility of Intervention in the Domestic Affairs of States and the Protection of Their

22 This Committee pronounced on self-determination because as he noted "ethnic or religious groups or minorities frequently refer to the right to self-determination as a basis for an alleged right to secession". In this connection the Committee wishes to express the following views (par. I).

23 In the number 6, the Committee points out this idea and said that: "The Committee emphasizes that, in accordance with the Declaration on Friendly Relations, none of the Committee's actions shall be construed as authorizing or encouraging any action which would dismember or impair, totally or in part, the territorial integrity or political unity of sovereign and independent States conducting themselves in compliance with the principle of equal rights and self-determination of peoples and possessing a Government representing the whole people belonging to the territory, without distinction as to race, creed or color. In the view of the Committee, international law has not recognized a general right of peoples unilaterally to declare secession from a State. In this respect, the Committee follows the views expressed in an Agenda for Peace (paras. I7 and following), namely, that a fragmentation of States may be detrimental to the protection of human rights, as well as to the preservation of peace and security. This does not, however, exclude the possibility of arrangements reached by free agreements of all parties concerned".

24 Para. 4 of the General Recommendation XXI.

${ }_{25}$ M., Kohen "La création d'Etats en droit international contemporain", in J. Cardona Llorens (dir.), Cursos Euromediterráneos Bancaja de Derecho Internacional, Vol VI (2002), 543-636, at 584. 
Independence and Sovereignty ${ }^{26}$. It had also been noted by some of the monitoring bodies established under various human rights treaties ${ }^{27}$. So obvious is it that self-determination and human rights are connected and mutually reinforcing that every year the UNGA reiterates the importance of the universal realization of the right of peoples to self-determination for the effective guarantee and observance of human rights and for the preservation and promotion of such rights ${ }^{28}$. However, it is one thing to promote respect for the human rights of the members of a people and their self-determination and quite another to consider that only through independence and the creation of a new state can respect for such rights be enforced.

Today, the most important aspects of self-determination are found in this internal aspect and its evolving nature. Its evolution, as a result of the relationship forged between respect for human rights, democracy and the self-determination of peoples, has led to the extension of the right to self-determination to certain groups.

Respect for human rights, including self-determination, and the representative nature of the government, which the Declaration of Principles presents as a guarantee of respect for the political unity and territorial integrity of the state ${ }^{29}$, take on special importance when a

${ }_{26}$ The General Assembly emphasized that. "every State has an inalienable right to choose its political, economic, social and cultural system without interference in any form by another State" (par. 5) and that: "all States shall respect of self-determination and independence of peoples and nations to be freely exercised without any foreign pressure and with absolute respect for human rights and fundamental freedoms. Consequently, all States shall contribute to the complete elimination of racial discrimination and colonialism in all its forms and manifestations" (par. 6).

${ }_{27}$ The general observations and recommendations made by the Human Rights Committee - General Comment no. I2 right of self-determination (Article I)(1984) - and by the Committee for the Elimination of Racial Discrimination - General Recommendation no. XXI on the right to self-determination (1996) - warn of the link between the right to self-determination and the corresponding obligations with the other provisions of the Covenant and the rules of International Law.

28 Under the title of Universal realization of the right of peoples to self-determination the General Assembly of United Nations adopts every year a Resolution to insist on the connection between the respect of selfdetermination and the observance of the others human rights, i.e., A/RES/72/159, I9 December 2017; A/RES/7I/I83, December 19, 2016; A/RES/70/I43, I7 December 2015; A/RES/69/164, I8 December 2014; $\mathrm{A} / \mathrm{RES} / 68 / \mathrm{I53}$, I8 December 2013. A connection which also is noted by Alfred-Maurice Zayas in his Interim Report of the Independent Expert on the promotion of a democratic and equitable International Order (Doc. A/69/272 Promotion of a democratic and equitable international order), par. 2 and that the General Observation I2 of the Human Rights Committee affirms; "The right of self-determination is of particular importance because its realization is an essential condition for the effective guarantee and observance of individual human rights and for the promotion and strengthening of those rights" (par. I).

29 In this sense, Eduardo Jiménez de Aréchaga noted that: "an independent and sovereign State which possesses a government representative of the whole of its people is thus safeguarded from any claim to selfdetermination by a part of its population. A contrario, a State possesses a government which does not represent the whole people of the territory and which introduces distinctions as the race, creed or color, is not protected by the safeguard clause and is exposed to actions which, in the name of the principle of self-determination may dismember or impair, totally or in part, its territorial integrity or political unity", E. Jiménez de Aréchaga, 
sovereign state's people is made up of distinct groups, whether for reasons of race, religion, language or any other aspect. When these groups are a minority, their members have the right to have their own cultural life, to profess and practice their religion, and to use their own language without discrimination (Articles 2, 25, 26 and 27 of the International Covenant on Civil and Political Rights).

In 2014, the Independent Expert on the Promotion of a Democratic and Equitable International Order, Alfred-Maurice Zayas, stressed the two aspects of self-determination and its evolving nature, since its exercise is a dynamic process subject to revision and adjustment. In his opinion:

"... the right of self-determination means that individuals and peoples should be in control of their destinies and should be able to live out their identities, whether within the boundaries of existing States or through independence. More than an outcome, self-determination should be seen as a process subject to revision and adjustment, and its outcome must correspond to the free and voluntary choice of the peoples concerned, within a framework of human rights protection and non-discrimination. Self-determination cannot be understood as a one-time choice, nor does it extinguish with lapse of time because [, 1]ike the rights to life, freedom and identity, it is too fundamental to be waived. As an ongoing democratic exercise, selfdetermination entails a people's equal participation in decision-making, a continuous dialogue by virtue of which parties adjust and readjust their relationship for mutual benefit. It can be exercised at various levels, from enhanced empowerment, regional autonomy and federalism to secession $[\ldots]$ ” (par. 3).

" $[\ldots]$ For human rights, peace, security and stability to flourish, the relationships between peoples and governmental entities must be based on genuine and continuing consent, on the understanding of a contrat social and, if this contrat is violated by Government, the people as sovereign have the democratic right to redefine the relationship [...]" (par. 8).

(D) THE NECESSARY CONDITIONS FOR A RIGHT OF REMEDIAL SECESSION TO EXIST The possibility of recognizing a right of remedial secession under the principle of selfdetermination of peoples requires a right-holder in the situation provided for by the aforementioned texts.

The term 'people' has never been conclusively defined; however, it would seem to have two identifying features, one objective, the other subjective. First, a population group is considered a people when it has a common historical tradition, an ethnic or racial identity, cultural homogeneity, linguistic unity, religious or ideological affinity, a territorial connection

\footnotetext{
"International Law in the Past Third of a Century. General Course in Public International Law", R. des. C., t.
} I59, (1978), I-344, at p. IIO. 
or a common economic life. Second, it must have an awareness of its existence as a people $3^{30}$ and a willingness to be recognized as such.

In this regard, it should be recalled that, although the term 'people' has not been defined under IL, today, at the tail end of the decolonization process, it is generally used to refer to the population of a sovereign state. This is because, as Marcelo Kohen notes, the legal approach to the concept of people is essentially territorial and thus makes the term 'people' coincide with the population of a sovereign state ${ }^{31}$. However, most states are multi-ethnic or multinational. Therefore, it is possible to identify various ethnic or national groups, minorities or otherwise, that may also be considered holders of the right to self-determination insofar as its internal aspect is concerned ${ }^{32}$.

The group deprived of its right to self-determination may include the entire population of the state. Such cases involve situations of widespread tyranny or oppression. Alternatively, it may consist of only part of the population, usually an ethnic or national people with a territorial base. In the context of remedial secession, only the latter case will be considered, as it generally involves a minority whose members have had certain rights recognized (Article 27, International Covenant on Civil and Political Rights) in a way similar to the recognition of the internal aspect of self-determination ${ }^{33}$. Such a situation does not deprive them of their autonomy ${ }^{34}$.

In what situations might a right of remedial secession be recognized for these peoples? According to the safeguard clause, they are situations in which the fundamental rights of the population, or part of it, are being violated, including the internal aspect of the right to selfdetermination. The question then becomes: what degree of violation of rights or lack of governmental representativeness is required to recognize a right of secession? Whilst the terminology used to refer to these situations and the conditions to be met varies, it consistently expresses gravity.

This issue is the subject of great debate in the literature and an exhaustive account would fall beyond the scope of this paper. Briefly, Judge Cançado Trindade may have taken the

$3^{30}$ It is the idea of people used by M. Kirby in the speech delivered at the International Meeting of Experts on the Rights of Peoples and Self-Determination, organized by UNESCO in Budapest (I99I), Provisional Report of the Independent Expert already cited supra n. 28, p. 4.

3I M. Kohen, "La création...." supra n. 25, at 585-586.

32 In this sense i.e., P. Andrés Sáenz de Santamaría, supra n. 3, at I52-I59; A. Cassese, supra n. I3, at IOI-IO8; F. Mariño Menéndez, "Naciones Unidas y el derecho de autodeterminación, in F. Mariño Menéndez (ed), Balance y perspectivas de Naciones Unidas en el cincuentenario de su creación, (Dykinson, Madrid, 2016), 77-IIO, at 87.

33 P. Andrés Sáenz de Santamaría, supra n. 3, at 194-198.

34 The United Nations warns that the rights of persons belonging to minorities differ from the right to selfdetermination. General Observation 23, April 8, 1994, The rights of minorities adopted by the Human Rights Committee ant the Doc E/CN.4/Sub.2/AC.5/2005/2, Commentary to the UN Declaration on the rights of persons belonging to national or ethnic, religious and linguistic minorities of the Working Group on Minorities. 
greatest pains to exemplify the situation. He speaks of situations of systematic oppression, subjugation and tyranny involving serious violations of fundamental rights - mass killings, torture, forced disappearances, ethnic cleansing, systematic discrimination - that are in breach of the corpus juris gentium, as set forth in the UN Charter and the Universal Declaration of Human Rights ${ }^{35}$. The most demanding positions are espoused by those who, in addition to citing serious violations of human rights, deem necessary the existence of an extreme threat to the people's life or survival ${ }^{6}$. Others, such as Cassese, hold that such a situation exists when there is a persistent refusal to recognize the right of the group's members to participate in the decision-making process, their human rights are seriously and systematically trampled, and they are denied the possibility of reaching a peaceful settlement within the framework of the structure of the state ${ }^{37}$. Still others speak of remedial secession in the context of massive and systematic human rights violations ${ }^{38}$ or the violation of the internal aspect of the right to selfdetermination ${ }^{39}$. Judge Yusuf identifies these situations as cases in which a group is subjected to discrimination, persecution and flagrant human rights or humanitarian law violations ${ }^{40}$. At the other end of the spectrum are authors such as Schachter, who cites only the existence of practices of systematic discrimination and the rejection of a reasonable proposal by the government of the state, or Buchanan, who cites massive and systematic human rights violations, but argues that the right also exists when a government violates agreements that afford a certain degree of self-government to a minority group ${ }^{41}$.

35 Paras. 175 y 205 of the separate opinion of judge Cançado Trindade, in which the judge considers that this situation had occurred in Kosovo with respect to the Albanians in the nineties of the last century, par. I8I, ICJ Reports, (2010), at 593, 605 y 595.

$36 \mathrm{CH}$. Tomuschat, "Secession and self-determination", in M. Kohen (ed.), Secession International Law Perspectives, (Cambridge University Press, Cambridge, 2006), 23-45, at 4I-42, this author speaks of structural discrimination in the sense of serious damage that affects human lives; D. Murswiek, "The Issue of a Right to Secession - Reconsidered", in CH. Tomuschat (ed.), Modern Law of Self-Determination, (Nijhoff, Dordrecht, Boston, London, 1993), 2I-40, at 38-39; R. Riquelme Cortado, supra n. 7, at 167, that refers to massive and systematic violations of the essential human rights of a people when they threaten their own existence; A. Remiro Brotons, Derecho Internacional. Curso general, (Tirant lo Blanch, Valencia, 20IO), at 127, speaks of peoples oppressed by genocide, massive violation of their rights, destruction of their identity or serious and systematic political and social discrimination.

37 A. Cassese, supra n. I3, at IOI-I4O. Recently L. Laurinaviciute and L. Bieksa, "The relevance of remedial secession in the post-Soviet 'frozen conflicts", International Comparative Jurisprudence, I, (2015), 66-75, at 67-69.

$3^{8}$ J. Castellino, International Law and Self-Determination, (Nijhoff, The Hague, 2000), at 39-4I.

39 A. Tancredi, "A normative "due process" in the creation of States through Secession", in M. Kohen (ed.), Secession International Law Perspectives, (Cambridge University Press, Cambridge, 2006), 171-207, at 177.

40 Separate opinion of judge Yusuf, pars. II y I2, ICJ Reports, (2010), pp 622-623.

${ }^{41}$ The opinion of this author was collected by A. Bennet, "When is Secession legitimate?", Laws526: Comparative Constitutionalism, (2014), at 2I-22. Bennet refers only to human rights violations. 
Here it should be noted that most supporters of the right of remedial secession emphasize that secession must be the remedy of last resor $t^{42}$. This requirement ${ }^{43}$ means that the parties must first have made a good faith effort to solve the problem by all means at their disposal and be willing to compromise.

In short, a variety of expressions have been used to identify the case that would give rise to a possible right of remedial secession. However, in view of the potential consequences, such a case would need to be especially serious. Therefore, it seems timely and prudent to specify the case at issue before analysing the possible existence of a customary IL rule recognizing this right. To this end, the common denominator seems to be the existence of a situation of massive and systematic violation of the fundamental rights of a people that threatens both its survival and that of its members and that can only be resolved through the creation of a new state. What situations might this include? In fact, this case is very similar to the situations once used to speak of the responsibility to protect, which the members of the UN unanimously specified as situations involving genocide, war crimes, ethnic cleansing and crimes against humanity ${ }^{44}$.

\section{(E) IS REMEDIAL SECESSION A RIGHT UNDER CUSTOMARY INTERNATIONAL LAW?}

At this point, we must ask whether IL has recognized a right of secession as a remedy for peoples who are victims of genocide, war crimes, ethnic cleansing and crimes against humanity. In other words, do they have the right to secede from the state to which they belong in order to form an independent state.

A review of the literature shows a diversity of opinions. Some authors argue in favour of its existence. Others, without stating a clear opinion on the matter, hold that its recognition should be in line with the evolution of IL. They argue that it is subject to the limitations of state sovereignty and the organization of state legitimacy on the basis of the protection of human rights and democracy ${ }^{45}$. Still others are more sceptical ${ }^{46}$. The same diversity can be

42 This term was used by Switzerland before the ICJ, Written Statement p. 24.

43 The most States supporters of the right of remedial secession before the ICJ demanded the concurrence of this requirement. I.e., Germany, 24; Ireland, 9; Netherlands, 9; Russian Federation, 22 and Switzerland, 24. In this sense, CH. Tomuschat, Modern Law of Self-Determination, (1993), at 26 and Hannun, "The Specter of Secession: Responding to Claims for Etnic-Self-Determination”, Foreign Affairs, vol II, (1998), at 16.

44 These are three of the four international crimes of competence of the ICC and ethnic cleansing, including, as the UN Secretary General warns, in the Final Document of the World Summit of September 16, 2005 (A/ RES/60, paras 138 and 139), because, although it is not a crime in international law by itself, the acts by which it proceeds may constitute one of the other three crimes, Doc A/ 63/677, Effective the responsibility to protect. Report of the Secretary General, para. 3.

$45 \mathrm{CH}$. Walter and A. Ungern-Sternberg, supra n. I at 6.

${ }^{46}$ Crawford, J., supra n. I, at 415-4I8; Driest, S. van den, Remedial Secession. A Right to External SelfDetermination as a Remedy to Serious Injusticies? (Cambridge, 2013), Cap. V y VI, at I89-296. 
found in the opinions of the Court's judges. Judge Cançado Trindade believes that populations suffering situations of systematic oppression, subjugation and tyranny have a right to self-determination (understood as secession or independence)47. Judge Yusuf argues that the creation of an independent state and questioning of a state's territorial integrity is justified in cases in which a group is subjected to discrimination, persecution and flagrant human rights or humanitarian law violations ${ }^{48}$. In contrast, Judge Koroma holds that positive IL does not recognize a right authorizing an ethnic, linguistic or religious group to separate from the state of which it forms a part without the latter's consent ${ }^{49}$.

47 In opinion of the Brazilian judge: "Human nature being what it is, systematic oppression has again occurred, in distinct contexts; hence the recurring need, and right, of people to be freed from it. The principle of self-determination has survived decolonization, only to face nowadays new and violent manifestations of systematic oppression of peoples.... It is inmaterial whether, in the framework of these new experiments, selfdetermination is given the qualification of "remedial" or another qualification. The fact remains that people cannot be targeted for atrocities, cannot live under systematic oppression. The principle of self-determination applies in new situations of systematic oppression, subjugation and tyranny" (par. 175); "No State can invoke territorial integrity in order to commit atrocities (such as the practices of torture, and ethnic cleansing, and massive forced displacement of the population), nor perpetrate them on the assumption of State sovereignty, nor commit atrocities and then rely on a claim of territorial integrity notwithstanding the sentiments and ineluctable resentments of the "people" or "population" victimized" ( 176$)$ and also ".the entitlement to self-determination of the victimized population emerged, as the claim to territorial integrity could no longer be relied upon by the willing victimizers" ( $\mathrm{I} 8 \mathrm{I})$. Cançado Trindade appeals the principal international instruments of the International Law of Human Rights, highlightst he third paragraph of the Preamble of the Universal Declaration of Human Rights in which it can be read: "Whereas it is essential, if man is not be compeled to have recourse, as a last resort, to rebellion against tyranny and oppression, that human rights should be protected by the rule of law". About the Universal Declaration, pars 20I-204.

48 Separate Opinion of judge Yusuf, pars. II y I2. ICJ Reports, (2010), 622-623. In opinion of the judge: "This does not, however, mean that international law turns a blind eye to the plight of such groups, particularly in those cases where the State not only denies them the exercise of their internal right of selfdetermination (as described above), but also subjects them to discrimination, persecution and egregious violations of human rights or humanitarian law. Under such exceptional circumstances, the right of peoples to self-determination may support a claim to separate statehood provided it meets the conditions prescribed by international law, in a specific situation, taking into account the historical context. Such conditions may be gleaned from various instruments, including the Declaration on Principles of International Law Concerning Friendly Relations and Co-operation among States in Accordance with the Charter of the United Nations, which, as stated by the Court in paragraph 80 of the Advisory Opinion, reflects customary international law. The Declaration contains, under the principle of equal rights and self-determination of peoples, the following saving clause.... This provision makes it clear that so long as a sovereign and independent State complies with the principle of equal rights and self-determination of peoples, its territorial integrity and national unity should neither be impaired nor infringed upon. It therefore primarily protects, and gives priority to, the territorial preservation of States and seeks to avoid their fragmentation or disintegration due to separatist forces. However, the saving clause in its latter part implies that if a State fails to comport itself in accordance with the principle of equal rights and self-determination of peoples, an exceptional situation may arise whereby the ethnically or racially distinct group denied internal self-determination may claim a right of external self-determination or separation from the State which could effectively put into question the State's territorial unity and sovereignty".

49 Dissenting Opinion of judge Koroma, para. 4: “...International law does not confer a right on ethnic, linguistic or religious groups to break away from the territory of a State of which they form part, without that 
In the proceedings for the advisory opinion of the International Court of Justice regarding the Accordance with international law of the unilateral declaration of independence in respect of Kosovo, the lack of consensus amongst the interveners was clear. It was possible to distinguish between those who denied the right existed ${ }^{\circ}$ and those in favour of its consolidation. The latter group could be further divided into those who believe it is provided for only very exceptionally and in situations of massive and systematic human rights violations as a last resor $^{5 \mathrm{II}}$ and those who did not advocate this latter requirement, viewing secession as a sort of sanction against the state responsible for the serious violation ${ }^{52}$. Additionally, some states, regardless of whether they referred to the right of remedial secession, noted that Kosovo was, in any case, a sui generis situation and that the case thus could not be considered a precedent ${ }^{5}$. As Cyprus noted ${ }^{54}$, and practice seems to be beginning to bear out, this may not be the case.

Even if there had been consensus amongst the participants before the Court, it might still not have been generalizable. This is because the states intervening before the Court were mostly Western states, essentially European ones. Few Asian, African and Latin American countries intervened before the Court, and only one non-Western one did, namely, Jordan, which spoke in favour of the existence of a right of remedial secession.

The necessary consensus to affirm the existence of an opinio iuris that supports the existence of a right of remedial secession in the situations and conditions outlined above is thus lacking. The notion that there exists an international custom that recognizes a right of remedial secession in cases of massive and systemic human rights or IHL violations is not a settled matter nor does there seem to be the necessary consensus to assert its existence and recognition under IL. The ICJ itself so recalled, both with regard to the existence of such a right and the circumstances in which it could be exercised, in its advisory opinion of 22 July 201055. Nevertheless, there are those who cite the Court's opinion and, in particular, the fact

State's consent, merely by expressing their wish to do so. To accept otherwise, to allow any ethnic, linguistic or religious group to declare independence and break away from the territory of the State of which it forms part, outside the context of decolonization, creates a very dangerous precedent. Indeed, it amounts to nothing less than announcing to any and all dissident groups around the world that they are free to circumvent international law simply by acting in a certain way and crafting a unilateral declaration of independence, using certain terms. The Court's Opinion will serve as a guide and instruction manual for secessionist groups the world over, and the stability of international law will be severely undermined".

so Written Statement to Argentina, Azerbaijan, Bolivia, Burundi, China, Cyprus, Spain, Iran, Serbia, Venezuela and Vietnam.

sI Written Statement to Estonia, France, Germany, Ireland, Maldives, Netherlands, Romania, Russian Federation and Switzerland.

52 Written Statement to Poland, par. 6.5.

53 Written Statement to France, Japan, Latvia, Luxembourg, Maldives and Slovenia,

54 Written Comments to Cyprus, pars. 28-40.

55 The ICJ warned that: ".... Whether, outside the context of non-self-governing territories and peoples subject to alien subjugation, domination and exploitation, the international law of self-determination confers 
that it did not condemn Kosovo's unilateral declaration of independence to support the consolidation of a right of remedial secession ${ }^{56}$.

With its advisory opinion, the Court has done a disservice to IL and to the stability of states. Indeed, Crimea used the opinion to support its Declaration of Independence on II March 20I47.

Let us imagine now that there was a consensus on the existence of a right of remedial secession in the case of peoples who are victims of genocide, war crimes, ethnic cleansing or crimes against humanity. The question remains of whether there exists the necessary general, constant, uniform and lasting practice to complete the process of custom formation.

In this regard, practice since the adoption of Resolution 2625 (XXV) likewise does little to confirm the existence of a customary law recognizing the right of remedial secession. I refer only to this more recent practice, as the practice prior to the resolution was insufficient and lacked the necessary uniformity ${ }^{-8}$ for the resolution to be viewed as the crystallization of a customary norm in formation.

A review of secession practice shows that, if one distinguishes between cases of dissolution and secession ${ }^{59}$, despite the increase in attempts since 1989 , few secession processes have successfully resulted in the creation of a new state. Furthermore, although some cases can be linked to alleged human rights or IHL violations, all have been influenced by other factors that have proved decisive. The most relevant such factor, without a doubt, is the recognition of the new state by the mother state, which usually leads to its recognition by the international community at large.

One possible case of remedial secession is Bangladesh (formerly, East Pakistan), where the Bengali people suffered harsh repression following the unrest resulting from the Pakistani

upon part of the population of an existing State a right to separate from that State is, however, a subject on which radically different views were expressed by those taking part in the proceedings and expressing a position on the question. Similar differences existed regarding whether international law provides for a right of "remedial secession and, if so, in what circumstances". In this sense, The Supreme Court of Canada in re Secession of Quebec, 1998, 2 S.C.R. 217, pars. I34-135.

56 A.G. López Martín and J.A. Perea Unceta, supra n. I3, p. I89 and R. Falk, "The Kosovo advisory opinion: conflict resolution and precedent", AJIL, vol. I05, (20II), 50-60, at 57-58.

57 A recent analysis of this question may be seen at A. Remiro Brotons, "Derecho y poder en el destino de Crimea, 34 Anuario Español de Derecho Internacional (2018), 23I-243 [DOI: I0.1558I/oro.34.23I-243].

58 On the secessions produced before 1979 and accepted by the international community only that of Finland (1917) could be considered a consequence of a discriminatory practice. Others, as Biafra, also with massive and systematic violations of human rights or IHL, did not prosper, A.G. López Martín and J.A. Perea Unceta, supra n. I3, pp. I7I-I74.

59 In this analysis I have considered as dissolution the process of the creation of Senegal, Singapore (both arise from the dissolution agreed or accepted by the two parties that made up the federation: The Federation of Mali between Senegal and Sudan French and the Federation formed by Malaysia and Singapore), and also the process related to the Former Soviet and Yugoslav Republics. 
president's refusal to recognize the result of an election won by the (Bengali) Awani League, transfer power and agree to its autonomist agenda (violation of the internal aspect of the right to self-determination and human rights violations). However, as such situations pose a threat to international peace and security, until India intervened, nobody called for the matter to be examined by the Security Council (SC). India's intervention was decisive in the result, which was accepted by the international community once Pakistan acknowledged the creation of the new state as a fait accompli.

The cases of Eritrea and South Sudan, which involved human rights and IHL violations, are also special. They could be considered separations or agreed secessions due to the existence in fine of an agreement between the parties. In both cases, the right to self-determination (of the Eritrean and South Sudanese peoples) had been recognized, and a commitment had been undertaken to hold a referendum on their independence, which took place in 1993 and $201 \mathrm{I}$ respectively.

The key to failed secessions seems to lie, first, in the lack of support from the mother state and, second, in the lack of acceptance by the international community, even in cases involving human rights violations. According to Crawford, the most obvious case is Somaliland, whose independence has been frustrated to a certain extent by the inexistence of a government with which to negotiate, which has also paralyzed some states' reactions ${ }^{60}$. Clearly, the success of a secession requires an agreement between the parties or the mother state's acceptance of it as a fait accompli.

There are also cases in which the existence of massive and systematic human rights violations has not led to the secession of the oppressed people. This would include the cases of, for example, the Tamils in Sri Lanka, the Kurds, who are spread out across four states (Turkey, Iraq, Iran and Syria), or the Chechens.

Thus, practice with regard to completed secessions, whether unilateral or agreed, accepted by the international community or otherwise, is insufficient to confirm the existence of a right of remedial secession in cases of massive and systematic human rights or IHL violations, even once all the constraints established for the case are considered ${ }^{6}$.

The practice of international organizations likewise reveals a certain reluctance on the part of their bodies to provide arguments in favour of the existence of this right. One need only look to the completed cases of secession that have been rejected by the SC or other international organizations. The SC deplored the establishment of the Turkish Republic of Northern Cyprus on part of the island, urging UN members not to recognize the new

60 J. Crawford, supra n. I, p. 417.

6r Some States that intervened before the ICJ highlighted the inadequacy of the practice. Written Statement to Cyprus, paragraph 153 and Written Statement to Iran paragraph 4.2. 
situation $^{62}$. More recently, the UNGA decried the lack of validity of the referendum held in the Autonomous Republic of Crimea and the city of Sevastopol that led to their independence and subsequent incorporation into the Russian Federation. It called upon all states, international organizations and specialized agencies not to recognize any change to their status and to refrain from any act or operation that could be interpreted as an acknowledgment of that modified status ${ }^{63}$.

The analysis of both state and institutional practice shows that it lacks the necessary generality and uniformity to be indicative, when viewed in conjunction with opinio iuris, of the emergence of a customary norm.

\section{(F) CONCLUSION}

General international law has not yet completed the path to recognizing a right of remedial secession for peoples subjected to massive and systematic violations of human rights and IHL, including the internal aspect of self-determination.

Whether or not this right is recognized will depend on how practice and views of its accordance with law evolve. Meanwhile, it should be borne in mind that the automatic application of rules regarding the self-determination of colonial peoples to other groups could be counterproductive and undermine international stability.

The situations of violence that lie at the root of the cases in which the right of remedial secession would apply are susceptible to manipulation by those seeking to appear as victims to the international community. The determination of whether or not such a situation exists should be left to an impartial body (Human Rights Committee) based on the application of clear objective criteria.

In the meantime, it should be recalled that, like the cases on which the responsibility to protect is based, the situations that would form the basis of a right of remedial secession pose a threat to international peace and security. The SC must be aware of its responsibility in this regard. However, as the Secretary General warned in his 2009 report Implementing the Responsibility to Protect, so should the UNGA ${ }^{64}$. The Independent Expert on the Promotion of a Democratic and Equitable International Order proposed that the UNGA consider establishing a special mechanism to monitor the reality of self-determination today, in particular the situation of unrepresented peoples and non-self-governing peoples who are not

62 SC Res. 54I, I8 November 1983.

63 Resolution 68/262, 27 March 2014, Territorial Integrity of Ukraine, pars. 5 and 6. Previously, the GA "Urges all parties to pursue immediately the peaceful resolution of the situation with respect to Ukraine through direct political dialogue, to exercise restraint, to refrain from unilateral actions and inflammatory rhetoric that may increase tensions and to engage fully with international mediation efforts", par 3 .

${ }^{64} \operatorname{Doc} \mathrm{A} / 63 / 677$, I2 January 2009, Implementing the responsibility to protect. Report of the Secretary General, pars. 6I-63. 
currently considered under Article 73 of the Charter. He further proposed assigning more targeted functions to the Fourth Committee of the General Assembly, so as to supervise the proper application of Chapter XI procedures, and to consider tasking the Human Rights Council with the examination of self-determination matters as a permanent item on its agenda or as part of the universal periodic review procedure, especially from the functional perspective of self-determination as a tool to promote international peace and security ${ }^{65}$.

${ }_{65} \operatorname{Doc} \mathrm{A} / 69 / 272$, par. 87 . 